\title{
Detorgan-3índía:
}

Telaah Pemikiran Kebangsaan

Volume 3 No 1 Tahun 2021 Hlmn. 14- 29

Artikel Masuk 21 Juni 2021 I Artikel Diterima 1 September 2021

\section{Refleksi Gerakan Politik Islam Indonesia H.O.S Tjokroaminoto Serta Relevansinya Terhadap Indonesia Masa Kini}

\author{
Dzulkarnain Jamil*
}

Universitas Islam Negeri Sunan Ampel Surabaya, Jl. Ahmad Yani No.117, Jemur Wonosari, Kec. Wonocolo, Kota Surabaya, Jawa Timur 60237

*Dzulkarnainjamil17@gmail.com

\begin{abstract}
Abstrak
Penelitian ini bertujuan untuk menemukan hal yang baru dalam pandangan H.O.S Tjokroaminoto tentang gerakan politik Islam Indonesia serta relevansinya dengan Indonesia masa kini, selain itu evaluasi kritis terhadap H.O.S Tjokroaminto tentang Gerakan Politik Islam yang terdapat dalam beberapa karyanya. Metode penelitian yang digunakan adalah penelitian pustaka dengan menggunakan metode Hermeneutika. Hasil penelitian ini adalah Gerakan Politik Islam seharusnya diarahkan untuk menghidupakan persaudaraan sesama anak bangsa dan menciptakan kemandirian yang sebenarnya melalui penggalian terhadap budaya luhur bangsa sehingga mampu menghasilkan manfaat yang sebesar-besarnya bagi seluruh lapisan masyarakat. Hakikat gerakan politik Islam H.O.S Tjokroaminoto dan relevansinya dengan Indonesia masa kini dapat menuntun kita menjadi manusia yang aktif dan kreatif serta inovatif dalam memperjuangkan hak-hak masyarakat secara umum. Gerakan politik islam yang berlangsung dengan tanpa persatuan tidak dapat menuju cita-cita dan tujuan utama yaitu membawa berkah bagi semesta.
\end{abstract}

Kata Kunci : Gerakan, Politik, Persaudaraan, Kemandirian

\begin{abstract}
This study aims to find new things in H.O.S Tjokroaminoto's view of the Indonesian Islamic political movement and its relevance to today's Indonesia, in addition to a critical evaluation of H.O.S Tjokroaminoto about the Islamic Political Movement which is contained in several of his works. The research method used is library research using the Hermeneutics method. The result of this research is that the Islamic Political Movement should be directed to revive the brotherhood of fellow nation's children and create true independence through exploring the noble culture of the nation so that it is able to produce the maximum benefit for all levels of society. The nature of the H.O.S Tjokroaminoto Islamic political movement and its relevance to today's Indonesia can lead us to become active, creative and innovative human beings in fighting for the rights of society in general. An Islamic political movement that takes place without unity cannot achieve its main goals and objectives, which is to bring blessings to the universe.
\end{abstract}

Keywords : Movement, Politics, Brotherhood, Independence
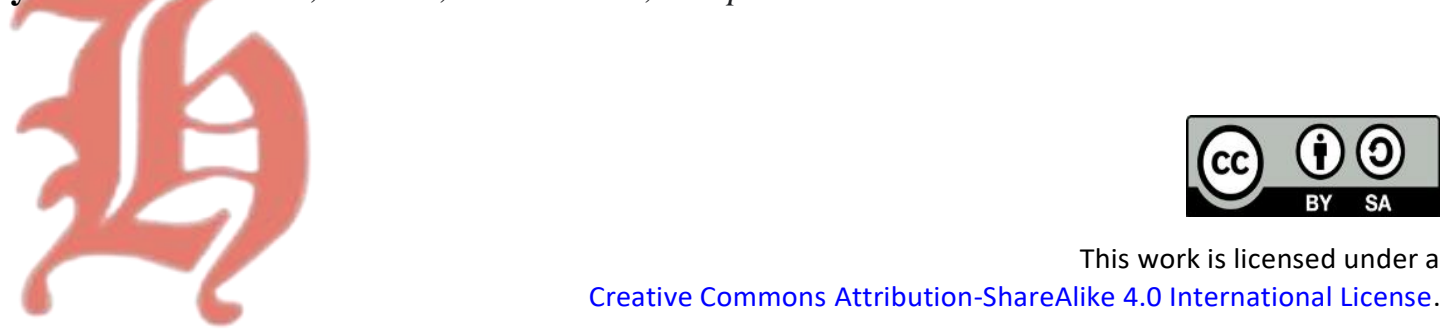

This work is licensed under a Creative Commons Attribution-ShareAlike 4.0 International License. 


\section{Dzulkarnain Jamil}

Sejarah (periodik), Sosok kenegaraan datang mengetuk hati terdalam seorang HOS Tjokroaminoto bahkan seketika sesaat HOS Tjokroaminoto baru dilahirkan kedunia ini. HOS Tjokroaminoto lahir pada 16 Agustus 1883 bersamaan dengan meletusnya gunung krakatau. Sebagaimana yang diketahui oleh umum bahwasanya berdasarkan silsilah keluarganya darah yang dimiliki oleh HOS Tjokroaminoto berasal dari kiai dan priayi. Yaitu dari ayah bernama R.M Tjokroamiseno, seorang Praja dengan pangkat Wejana di Kleco, Madiun. kakeknya, R.M. Adipati Tjogronegoro, pernah menjabat sebagai seorang Bupati Ponorogo. Kemudian buyutnya seorang ulama yaitu Kiai Bagoes Kesan Besari, pemilik pondok pesantren di Tegal Sari, Ponorogo. selanjutnya melalui perkawinannya dengan putri dari susuhanan Paku Buwoni III, Kesan Besaru melahirkan putra, yaitu Raden Mas Adipati Tjokronegoro yang kemudian menjadi Bupati Ponorogo. (Mulawarman 2020 12-13).

Seterusnya diketahui pula bahwasanya dalam segala sisi pada ruang dan waktu saat itu HOS Tjokroaminoto telah memenuhi kriteria layak sebagai seorang yang menikmati hidup nyaman dan senang bahkan penuh hura-hura sebagaimana manusia lainnya pada saat itu yang suka bergaya dengan mengandalkan kepangkatan yang dimiliki trah keturunannya karena telah tersedia fasilitas yang diberikan oleh Belanda. Sebagai penjajah tujuannya tidak lain sebenarnya untuk mengokohkan pendudukan dan dominasinya di tanah Nusantara ini.

Kemudian langkah tersebut sebenarnya merupakan kolaborasi yang sempurna dalam melakukan penindasan berkelanjutan. Hal yang perlu diingat kenapa pada saat itu kerajaankerajaan Nusantara memilih untuk merapat dengan kehadiran Belanda dikarenakan kerajaankerajaan di Nusantara sendiri mengalami gejolak-gejolak peperangan sehingga untuk mengamankan kedudukannya diperlukanlah kolaborasi licik dan picik yang hanya memikirkan kesenangan dirinya dan keluarganya saja.

Berangkat dari keterkungkungan rakyat dalam keadaan kemiskinan struktural tersebut, terbukalah mata hati HOS Tjokroaminoto. Beliau menyadari ada sesuatu yang kurang tepat dengan keadaan manusia ditindas di atas tanah kelahirannya sendiri sedangkan kekayaan alamnya dirampok besar-besaran guna memenuhi kebutuhan orang-orang Belanda dan keperluan untuk memperkaya diri sendiri dengan monopoli perdagangan diseluruh dunia dengan bahan hasil rampokan di tanah nusantara. Sebagaimana yang menjadi perjuangan HOS Tjokroaminoto dalam dominasi tersebut meluncurkan berbagai mosi pada Kongres Nasional Serikat Islam kedua Oktober pada tahun 1917 di Batavia. Seperti:

"Mosi penghapusan perkebunan yang banyak menyengsarakan rakyat akibat kebijakan Particuliere Lenderijen (Penguasaan tanah oleh tuan tanah) yang dibuat oleh Belanda melalui Undang-undang Agraria 1870, Mosi perbaikan irigasi, nasionalisasi perusahaan-perusahaan industry yang bersifat monopolistic serta bersentuhan dengan kepentingan hajat masyarakat banyak, seperti tekstil, besi, minyak dan gas, air serta listrik". (Mulawarman; 2020:81)

Meskipun demikian perlawanan terhadap ketimpangan yang terjadi di tengah masyarakat membuat percikan api perjuangan secara perlahan dimulai. Seperti yang dikatakan oleh HOS Tjokroaminoto dalam pidatonya pada pembukaan kongres tanggal 17 Juni 1916 di Bandung:

"Orang semakin lama semakin merasakan, bahwa tidak pantas lagi bagi Hindia diperintah oleh negeri Belanda, bagaikan tuan tanah yang menguasai tanahtanahnya. Tidak pada tempatnya menganggap Hindia sebagai seekor sapi perahan yang hanya diberi makan demi susunya; tidaklah pantas menganggap negeri ini sebagai tempat kemana orang berdatangan hanya untuk memperoleh keuntungan, dan sekarang sudah tidak pada tempatnya lagi bahwa penduduknya terutama anak negerinya sendiri, tidak mempunyai hak untuk turut berbicara dalam soal-soal pemerintahan yang mengatur nasib mereka," (Rambe, Safrizal 2008), (Mulawarman 2020:3) 
Kesadaran mendalam yang dirasakan oleh HOS Tjokroaminioto yang merasa senasib dengan masyarakat di sekitarnya yang hak-haknya dikebiri bahkan untuk menyamakan dirinya dengan masyarakat, HOS Tjokroaminoto menghilangkan gelar ke priayi-an yang dimilikinya dengan menggatikannya dengan gelar Haji. Kesadaran tersebut adalah langkah awal yang ditempuh HOS Tjokroaminoto dalam membela kepentingan masyarakat yang ada di tanah Nusantara.

Karya-karya Pemikiran H.O.S Tjokroaminoto. Seiring perjalanan kebangsaannya selalu mengukir pemikirannya dalam sebuah karya. Baik dituangkan pada media cetak maupun dibukukan. Entah merupakan gagasan terbaiknya maupun diharapkan agar dijadikan panduan dasar dalam menjalani perjuangan kemerdekaan oleh masyarakat Indonesia. Diantara karya terbaiknya yang dibukukan diantaranya sebagai berikut : Pertama, Muslem Nationaal Onderwijs. Kedua, Islam dan Nasionalisme. Ketiga, Islam dan Sosialisme (1924) buku ini ditulis pada tahun 1924 dan diterbitkan oleh penerbit Bulan Bintang Jakarta. Keempat, Tarikh Agama Islam (1931) buku ini dituliskan pada tahun 1931 diberbagai media cetak dan diterbitkan menjadi buku pada tahun 1963 oleh panggalin dan penghimpun sejarah Revolusi Indonesia di Jakarta. Kelima, Memerikasai Alam Kebenaran buku ini merupkan magnum opus dari karya H.O.S Tjokroaminoto yang mengulas menegenai bagaimana semestinya kehidupan masyarakat dengan perpaduan aspek duniawi dan ukhrawi. Keenam, Tafsir Program Asas Dan Program Tandzim 1930. Ketujuh, Reglemen Wasiat untuk Ummat (1934) buku ini ditulis pada 1934 dan disahkan oleh kongres PSII di Banjarnegara pada tanggal 20-26 Mei 1934.

\section{Hasil Dan Pembahasan}

H.O.S Tjokroaminoto: Guru Bangsa dalam kemerdekaan Indonesia. Dalam karyakaryanya maupun dalam gerakannya sehari-hari. H.O.S Tjokroaminoto memberikan pedoman kepada segenap masyarakat yang ada. Betul juga dapat dikatakan bahwa rangsangan yang diberikan oleh HOS Tjokroaminoto kepada segenap masyarakat untuk ikut andil dalam memikirkan persoalan bangsa.

Sebagaimana teriakan Zelfbestuur yang lantangkan sebagai bentuk penolakan terhadap penindasan. Itu merupakan bentuk perlawanan yang dilakukan oleh HOS Tjokroaminoto dalam menghadapi ketakutan dan tindakan represif yang seringkali dilakukan oleh penjajah. Kesadaran tersebut merupakan sebuah pendidikan yang paling penting ketika diaplikasikan dalam kehidupan keseharian HOS Tjokroaminoto dengan memberikan suri tauladan untuk peduli kepada sesama manusia bahkan ketika yang lain merasakan sakit dirinya sendiri juga merasakan sakitnya. Oleh karena kecintaannya pada tanah air yang menghidupinya setiap detik dan setiap saat hembusan nafasnya. Sehingga, tidak salah jika kemudian HOS Tjokroaminoto mengabdikan dirinya untuk sepenuh-penuhnya kepentingan seluruh umat manusia yang juga berada diatas tanah air Nusantara yang mengalami penindasan dan kesengsaraan.

HOS Tjokroaminoto sangat memahami tugas mulianya sebagai khalifah dan Abdillah di muka bumi ini telah membawanya menuju tak terlampaui Seperti HOS Tjokroaminoto yang menyebutkan tahapan agar mencapai kehidupan yang sejati:

"(1)Mengenal allah melalui jalan kebenaran serta kepercayaan kepada allah sejati, (2) mempelajari keindahan sempurna yang hanya ada pada allah itu sendiri, (3) membuktikan kebenaran sifat allah yang maha murah, (4) memohon pertolongan utama hanya berdo'a kepada allah, (5) mengeluarkan kekayaan, mempergunakan segenap kekuatan, keilmuan, mengorbankan jiwa dijalan allah. (6) menguatkan hati atas segala cobaan dan mengedepankan sabar, (7) membangun relasi sosial dalam lingkungan masyarakat ibadah dan kesempurnaan tauladan, (8) berpedoman pada tanda-tanda dan simbol-simbol kesucian allah". (Tjokroaminoto 1950,76-79). 


\section{Dzulkarnain Jamil}

Inilah pendirian penulis bahwasanya yang dilakukan oleh HOS Tjokroaminoto karena HOS Tjokroaminoto sendiri tidaklah penting bagi dirinya sendiri. Itu merupakan nilai religius yang dibawa oleh sosok HOS Tjokroaminoto yang telah diinstal dalam jiwa dan raganya bahkan batinnya. Menghilangkan kepentingan pribadi dapat menggerakkan perlawanan pada nilai tertinggi sebuah perjuangan. Sehingga terwujudlah perpindahan peradaban sebagaimana yang disebutkan oleh Dzulkarnain Jamil dalam Tulisannya: " ketika bangunan pengetahuan tersebut telah dikokohkan langkah selanjutnya adalah melakukan rekonsolidasi sesama hamba allah yang juga memiliki kesadaran yang sama ..." (Jamil.D : 2020)

Berdasarkan instituisi yang dimiliki oleh HOS Tjokroaminoto akhirnya beliau melihat begitu pentingnya gerakan politik sebagai dasar perjuangan untuk mencapai pemerintahan sendiri. Kemudian beliau berinisiatif mengubah organisasi Serikat Dagang Islam yang semula memiliki fokus dalam dunia perdagangan menjadi gerakan politik yang universal pada kongres Serikat Dagang Islam tahun 1912 di Surabaya.

Serikat Dagang Islam yang didirikan oleh Haji Samanhoedi di Solo pada tanggal 16 Oktober 1905 yang kemudian lewat kongres tersebut juga H.Samanhudi menyerahkan kepemimpinannya kepada HOS Tjokroaminoto. Tujuan awal berdirinya Serikat Islam sebagai perlawanan terhadap pedagang China yang saat itu mulai mendomenasi Nusantara akibat dari berhasilnya revolusi China pada tahun 1911. Revolusi tersebut berhasil menyingkirkan Puyi, Kaisar terakhir China dari dinasti Qing. (Tempo Seri Bapak Bangsa; 2011). Kemudian Serikat Dagang Islam akhirnya berubah menjadi gerakan politik. Hal itu terjadi seiring peristiwa Kongres Serikat Dagang Islam di Surabaya pada tahun 1912 yang dalam kongres tersebut mengubah konsep pergerakan di bidang ekonomi menjadi organisasi pergerakan yang berorientasi sosial-politik. (Tjokroaminoto:1924)

Perubahan tersebut seiring berjalannya waktu berbuah positif. Hal itu ditandai dengan meningkatnya keanggotaan serikat Islam yang kian bertambah hingga akhirnya mencapai 2,5 juta anggota pada tahun 1919. Dari anggota yang semula pada bulan Juni 1912 memiliki 2.000 anggota, kemudian mengalami peningkatan menjadi 35.000 pada bulan Agustus dan bertambah menjadi 40.000 pada bulan Desember. Pada 26 Januari 1913 kemudian mengalami peningkatan menjadi 80.000. dan melonjak menjadi 200.000 pada tanggal 23 Maret 1913 saat kongres di Surakarta. 440.000 pada tahun 1914 ketika kongres di Yogyakarta. Yang kemudian menuju 800.000 pada saat kongres Nasional di Bandung. Dan mengalami puncaknya pada saat kongres CSI Nasional tahun 1919 yaitu 2.500.000 anggota. (Mulawarman A.D 2020:5-6)

Pencapaian HOS Tjokroaminoto dapat terjadi karena beliau tidak lagi mementingkan dirinya maka kemudian namanya kian hari menjadi sosok yang diidolakan oleh khalayak ramai. Bahkan diberikanlah julukan-julukan seperti "Sang Juru selamat", "Ratu Adil", "Gatot Kaca" dan lain sebagainya. Walaupun dalam beberapa kesempatan HOS Tjokroaminoto sendiri menyangkal julukan yang diberikan kepadanya. Sebagaimana dalam pidatonya pada saat pembukaan kongres tanggal 17 Juni di Bandung yang mengatakan:

"Meskipun jiwa kita penuh dengan harapan dan keinginan yang besar, kita tidak pernah bermimpi tentang datangnya ratu adil. Atau kejadian yang bukan-bukan, yang kenyataan tidak pernah terjadi. Tapi kita akan terus mengharapkan dengan ikhlas dan jujur akan datangnya status berdiri sendiri bagi Hindia Belanda . . . Tuan-tuan jangan takut, bahwa kita dalam rapat ini berani mengucapkan perkataan Zelfbestuur atau pemerintahan sendiri ..." dikutip dari (Mulawarman A.D, 2020:4) (Suryanegara $(2013 \mathrm{M} / 1434 \mathrm{H}, 338)$

Maka dari itu juga erat kaitannya agar masyarakat tidak mengkultuskan dirinya dan memberikan harapan-harapan sepenuhnya kepada HOS Tjokroaminoto. Sehingga daya juang yang dimilikinya akan melemah karena ketergantungan hanya kepada satu tokoh saja atau terjadinya harapan-harapan milenaristis yang tak terhindarkan. Sangkalan tersebut tentu dilakukan oleh HOS Tjokroaminoto karena ketidak mampuan beliau membendung tingginya popularitas yang 
dimilikinya dan HOS Tjokroaminoto sendiri tidak membutuhkan hal tersebut. Bahkan ada sebagian orang merasa hal tersebut terlalu berlebihan sebagaimana yang dikisahkan oleh Haji Agus Salim yang merupakan teman perjuangan HOS Tjokroaminoto yang dikutip dalam buku 100 tahun Haji Agus Salim (1996;59) yang mengatakan:

"Pada waktu HOS Tjokroaminoto berjalan melewati orang-orang itu, mereka berjongkok di tanah dan mencium kakinya, sambil mengatakan pujaan-pujaan yang tidak saya senangi”.

Maka tidak heran kalau HOS Tjokroaminoto menyangkal julukan-julukan yang diberikan tersebut sebagai bentuk kekhawatirannya terhadap pandangan yang salah kaprah terhadap dirinya yang mengakibatkan penyimpangan-penyimpangan keyakinan dikemudian hari.

Konsep Gerakan Kebangsaan dalam Pandangan H.O.S Tjokroaminoto. Religiusitas, Semangat ketuhanan yang dibawa oleh HOS Tjokroaminoto dalam setiap langkahnya membuat segala sesuatunya memiliki nilai-nilai yang sulit ditemukan pada sosok lain. Karena hal tersebut begitu sulit untuk dikerjakan ketika menyangkut kepentingan dan kesenangan sendiri.

Pelibatan Tuhan dalan segala aktifitas yang dilakukan dan dibicarakan oleh HOS Tjokroaminoto membuat setiap langkahnya senantiasa mendapatkan kemudahan. Meskipun hal itu tentulah dibarengi dengan kesulitan-kesulitan juga.

Seperti peristiwa pernikahan kedua HOS Tjokroaminoto, dengan seorang seniwati idealis yang dilaksanakan pada antara bulan Februari-Mei tahun 1918, selalu dihembuskan sebagai tindakan, yang tidak terpuji karena Ibu Roestina mantan seorang penari di Surakarta. Kemudian kesedihan mendalam ketika HOS Tjokroaminoto ditinggalkan oleh teman hidup beliau yaitu istri pertama beliau, Soeharsikin yang kemudian dimakamkan di Botoputih Surabaya. Selanjutnya pemeriksaan yang berulangkali dilakukan oleh Belanda Sebelum dirinya ditangkap pada tahun 1921.

Fitnah lainnya yaitu Tjokroaminoto menghadiri Kongres Alam Islam di Makkah tahun 1926 perlu diketahui bahwasanya kongres Al-Islam dibentuk pada 31 Oktober- 2 September 1922 di Cirebon, disamping menghadiri kongres tersebut HOS Tjokroaminoto juga menunaikan ibadah haji dengan Ibu Roestina. Yang kemudian memunculkan Fitnah yang dihembuskan oleh kawan dekatnya sendiri yaitu Haji Misbach. Yang dianggapnya istrinya tersebut perempuan yang tidak berkelakuan baik. Tidak berhenti disitu, tekanan kepada HOS Tjokroaminoto dating bertubi-tubi seperti yang selanjutnya terjadi pada tahun 1927 Muhammadiyah tiba-tiba memveto terjemah tafsir Qur'an yang dikerjakan oleh Tjokroaminoto padahal pengerjaan proyek itu telah disetujui oleh Kongres SI pada tahun 1925.

Selanjutnya ada yang menganggap bahwa HOS Tjokroaminoto menggelapkan uang organisasi Majelis Ulama yang dibentuk atas prakarsa Serikat Islam pada tahun 1927, yang kemudian dilanjutkan oleh fitnah mengenai pengelolaan keuangan Martodirejo organisasi Persatuan Pegawai Pegadaian Hindia (PPPH) tahun 1933.

Padahal HOS Tjokroaminoto sebenarnya tidak terkait langsung dengan masalah keungan, tetapi karena tuduhan tokoh Serikat Islam sendiri, yaitu, Soekiman dan Soejopranoto, masalah tersebut akhirnya merambat kepada HOS Tjokroaminoto. Walaupun pada akhirnya kongres pada bulan Maret tahun 1933 mengeluarkan mereka berdua. Berlanjut pada perpecahan Serikat Islam Cabang Jogjakarta terbelah menjadi dua atas pemecatan tersebut.

Perpecahan ditubuh Serikat Islam juga sebenarnya merupakan hantaman yang luar biasa bagi HOS Tjokroaminoto dalam perjalanan hidupnya. Seperti halnya mulai kontranya muridmurid HOS Tjokroaminoto dengan beliau sendiri seperti pendirian Partai Nasional Indonesia pada tahun 1927 oleh Muridnya Yaitu Soekarno. 


\section{Dzulkarnain Jamil}

Perlawanan yang provokatif juga dilakukan oleh Semaoen salah satu muritnya yang tergabung dengan ISDV (Indische Social Democratische Vereniging) pada tahun 1915 di Surabaya yang merupakan bentukan Sneevliet yang melakukan kritik terhadap HOS Tjokroaminoto yang tergabung dengan Volksrad atau dewan rakyat bentukan Belanda yang akhirnya membuat HOS Tjokroaminoto memundurkan diri dari Volkrsad. Tidak hanya itu akan tetapi semaoen juga mempertanyakan substansi sekaligus melakukan penolakan islam sebagai pusat gerakan yang digagas HOS Tjokroaminoto pada Kongres Nasional pertama Centraal Serikat Islam di Bandung pada tahun 1916.

Selain Semaoen, Musso murid HOS Tjokroaminoto juga massif melakukan gerakangerakan perlawanan walaupun menyebabkan kerusuhan seperti kericuhan Serikat Islam Afdeling (Wilayah) B di Jawa Barat pada 1919. Juga perlawanan-perlawanan lain seperti perlawanan di Garut, Jawa Barat; dan Toli-toli Sulawesi. Dan peristiwa pemberontakan Partai Komunis Indonesia pada November tahun 1926.

Akan tetapi perpecahan dari kalangan murid-muridnya tersebut menandakan bahwasanya ruang diskusi menjadi basis pendidikan yang diselenggarakan oleh HOS Tjokroaminoto. Hal itu terbukti ketika muridnya berbeda haluan ideology yang dijalankan berarti HOS Tjokroaminoto tidak memaksakan pemikirannya untuk dianut secara signifikan, melainkan memberikan kebebasan untuk mendiskusikan setiap perbedaan yang ada dengan tetap tidak keluar dari lingkup Religius berkebangsaan. Namun, walau bagaimanapun juga HOS Tjokroaminoto benar-benar meresapi bahwa dirinya dengan orang lain pada kenyataannya adalah satu. Sebagaimana yang disampaikan oleh H.O.S Tjokroaminoto
"Kemerdekaan, persamaan dan persaudaraan adalah islam. Pikiran boleh berbeda dan pikiran itu selalu baik. Namun, yang berbahaya bila tangan dipergunakan untuk menerjemahkan kata-kata dengan kekerasan. Islam adalah salam perdamaian, islam adalah perjuangan untuk menuju kehidupan yang lebih baik" (Tjokroaminoto, 1924).

Sehingga nilai-nilai luhur tertang kerjasama begitu dikedepankan dan menjadi sesuatu yang menjadi fokus perjuangannya. Bahwasanya penyatuan seluruh masyarakat haruslah diwujudkan dengan tanpa melihat perbedaan-perbedaan yang menjadi pembatas sebagaimana yang biasanya dikedepankan oleh orang-orang pada masa itu seperti berdirinya organisasi Budi Otomo pada tanggal 20 Mei 1908 yang hanya mengumpulkan orang Jawa dan Madura saja yang didominasi oleh kaum priayi. Sehingga hal tersebut menjadikan pergerakan Boedi Oetomo tumpul walaupun disamping itu Boedi Oetomo telah menjadi organisasi pemula kedua yang oleh Muhammad Hatta disebut "Kecambah semangat kebangsaan Nasional".

HOS Tjokroaminoto dalam menyikapi perbedaan salah satunya adalah dengan menghembuskan karya-karya berupa tulisan sebagai bentuk merekatkan persatuan dengan mempengaruhi pola pandang dan pemikirannya melalui tulisan tersebut. Seperti ketika massifnya gerakan penyebaran ideologi oleh Semaoen, Beliau HOS Tjokroaminoto menulis buku yang berjudul Islam dan Sosialisme pada tahun 1924 sebagai bentuk perlawanannya.

Hal tersebut juga menandakan bahwasanya kebangkitan yang dibangun oleh HOS Tjokroaminoto benar-benar disadari bahwasanya haruslah tetap melibatkan orang-orang disekitarnya dan juga berharap bimbingan allah tuhan yang maha esa. Sebagaimana yang dilakukan oleh HOS Tjokroaminoto dan Haji Agus Salim saat mendeklarasikan federasi dengan nama Perhimpunan-Perhimpunan Politik Kebangsaan Indonesia (PPPKI) di Bandung pada tanggal 17-18 Desember 1927. Yang dalam hal tersebut beranggotakan Partai Serikat Islam, Boedi Oetomo, Partai Nasional Indonesia, Pasundan, Sumatra Bond, Serekat Madura, Kaum Betawi, ISC dan lainnya. Dengan tujuan kesatuan aksi untuk bersama mewujudkan kemerdekaan nasional Indonesia. (Mulawarman A.D 2020:161) 
Pendidikan, Kemudian pendidikan menjadi perhatian HOS Tjokroaminoto seperti gagasan mengenai Moslem Nasional Onderwijs (Pendidikan kebangsaan seorang muslim) pada tahun 1917. Hal tersebut tidak luput dari politik etis yang mulai dilakukan oleh Belanda pada tahun 1901 sebagai langkah lanjutan dari penjajahan dengan kamuflase rencana edukasi, irigasi dan migrasi. Tujuan pendidikan di Indonesia kala itu adalah untuk memproduksi tenaga kerja yang diperlukan oleh negara dan kegiatan bisnis swasta Belanda, menuntun bumiputera menuju modernitas yang dilakukan dengan gaya barat (Shiraishi, 2005:37)

Tujuan tersebut dapat dibuktikan dengan adanya pembatasan pendidikan pesantren yang dilakukan oleh Belanda pada tahun 1905 dengan memberlakukan ordonansi guru yang mewajibkan guru agama islam meminta dan memperoleh izin terlebih dahulu sebelum melaksanakan tugas sebagai guru agama. Selain itu, HOS Tjokroaminoto melihat Ekspresi yang beraneka ragam dari perjuangan-perjuangan yang dilakukan oleh bangsa-bangsa lain yang mulai bermunculan di negara-negara lain seperti perang dunia pertama pada tahun 1914-1918 kemudian revolusi Bolshevik di Russia pada tahun 1917. Hal tersebut dihawatirkan oleh HOS Tjokroaminoto dapat memberikan pengaruh kepada masyarakat yang sedang naik semangat dalam mengekspresikan kemerdekaan.

Perlawanan terhadap kungkungan penjajah tidak bisa dan tidak dapat dilakukan jika masyarakat masih mengenyam pengajaran-pengajaran yang diberikan oleh pendidikan Belanda. Karena didalam pengajaran tersebut tentu akan terdapat agenda tersembunyi seperti penjajahan moral dan budi pekerti kepada masyarakat. Hal itu terbukti ketika masyarakat tidak lagi memperhatikan bagaimana perilaku dengan budi yang luhur dengan mengedepankan akhlak dalam memperjuangkan kemerdekaan. Seperti melakukan perlawanan dengan agresif dengan sesekali menggunakan kekerasan. Hal tersebut tentu membuat hati HOS Tjokroaminoto kemudian mengalami rasa gelisah mengenai keadaan tersebut.

Sehingga HOS Tjokroaminoto melihat diperlukan bimbingan dan arahan yang tepat untuk mempersiapkan masyarakat yang mengedepankan nilai-nilai luhur dan budi pekerti dengan tetap berlandaskan nilai-nilai islam. Sepeti yang dikatakan oleh HOS Tjokroaminoto dalam kutipan berikut:

"Dimana asas islam itu adalah asas yang menuju Democratie dan Socialisme (Sosialisme sejati yang berlandaskan islam), dan asas tersebut juga bermaksud akan tercapainya kemerdekaan ummat dan kemerdekaan negeri tumpah darah, maka kalau kita kaum muslimin mendirikan sekolah-sekolah sendiri, tak boleh tidak pengajaran yang diberikan di dalamnya haruslah pengajaran yang mengandung pendidikan yang akan menjadikan muslim yang sejati dan bersifat nasional dalam arti kata: menuju maksud akan tercapai cita-cita kemerdekaan umat" (Amelz:1952)

Tidak dapat diragukan lagi bahwa pentingnya mengurus masyarakat dengan memperhatikan aspek Religius-kultural yang berada disekitar masyarakat merupakan sebuah langkah yang tepat. Karena tidak mungkin dan tidak bisa masyarakat majemuk yang masing-masing komoditas memiliki spesifikasi dan karakter religious-kultural yang berbeda ini dicekoki menggunakan pendidikan yang seragam ala pendidikan Eropa yang pada waktu itu adalah Belanda. Oleh sebab itu pendidikan merupakan sebuah kebutuhan dalam kehidupan masyarakat. Karena pendidikan merupakan langkah awal dalam pembangunan peradaban. Yang menjadi soalan selanjutnya adalah pendidikan yang bagaimana yang dapat mensejahterakan masyarakat secara utuh baik lahir dan batin?

Pendidikan yang memperhatikan aspek religius-kultural yang seutuhnya menyentuh persoalan kemanusiaan yang tidak bersifat diskriminatif dari sudut manapun juga. Sehingga nantinya pendidikan tersebut mampu menjawab semua persoalan hidup masyarakat baik ekonomi, social, budaya dan karakter yang tujuan akhirnya adalah perbaikan akhlak. Tidak heran jika pendidikan yang intensif menjadi program perjuangan selanjutnya oleh HOS 


\section{Dzulkarnain Jamil}

Tjokroaminoto sehingga dalam menanamkan kecintaan terhadap tanah air tetap dapat mendidik masyarakat untuk mempunyai budi yang luhur sehingga menjadi muslim yang sejati dengan memperhatikan akhlak dalam berperilaku. Karena islam sendiri tidaklah melarang manusia untuk mencintai tanah airnya sebagaimana yang ditegaskan pada kata-kata "Hubbul wathan minal iman" yang artinya cinta tanah air bagian dari iman.

Kaitan akhlak terhadap perilaku sehari-hari merupakan persoalan yang paling fundamental hal tersebut ditandai dengan tujuan baginda Rasulullah SAW kemuka bumi diturunkan tidak lain adalah untuk menyempurnakan akhlak. Sebagaimana dalam sebuah hadits yang diriwayatkan dari Abu Hurairah Radhiallahu "Anhu, Rasulullah Shallallahu 'Alaihi Wasallam bersabda "Innama bu'istu liutammima makarimal akhlak": yang artinya "Sesungguhnya aku diutus untuk menyempurnakan Akhlak". Begitu pentingnya akhlak pada perilaku manusia dalam menjalani kehidupan sehingga Allah mengutus nabi Muhammad secara langsung. Pendidikan juga hingga hari ini menjadi salah satu persoalan yang paling bermasalah oleh sebab itu persoalan-persoalan yang disentuh oleh HOS Tjokroaminoto benar-benar persoalan yang menjadi masalah krusial ditengah-tengah masyarakat. Makanya tidak heran jika HOS Tjokroaminoto kerap kali didengungkan sebagai orang yang melampaui dirinya.

Persaudaraan, H.O.S Tjokroaminoto melihat pentingnya penyatuan diri masyarakat antara yang satu dengan yang lain dan dirinya dengan tuhannya. Sebagaimana pemikiran beliau yaitu Keselamatan dan kemaslahatan bersama haruslah memiliki dua orientasi yaitu dunia dan akhirat. Hal tersebut juga erat kaitannya dengan tujuan pemberian akal kepada manusia agar senantiasa berfikir dan merenungkan bahwa keberadannya tidaklah dapat hidup secara individual karena walaupun bagaimana kita menolak untuk membutuhkan orang lain paling tidak ketika meninggal dunia masih tetap membutuhkan orang lain untuk mengantarkan ke Liang lahat dan menguburkannya. Kemudian dalam menjalani kehidupan ini dibutuhkan untuk merefleksikan kembali bagaimana hubungan manusia dengan manusia lain sehingga terbentuklah apa yang disebut oleh HOS Tjokroaminoto dalam pembukaan buku Sosialisme dan Islam :

\section{"Kaanan nasu ummatan wahidatan"}

Sesungguhnya seluruh umat manusia itu bersaudara/bersatu, begitulah pengajaran di dalam AlQur'an yang suci, yang menjadi dasar sosialisme. Kalau segenap umat manusia kita anggap sebagai satu persatuan, tidak boleh tidak wajib kita berusaha untuk mencapai keselamatan bagi mereka semuanya. (Tjokroaminoto:1924:37)

Kesadaran yang mendalam HOS Tjokroaminoto mengenai pesan-pesan yang disampaikan oleh Allah dalam Al-Qur'an membentuk perilakunya dalam memperjuangkan hakhak sesama manusia yang akhirnya juga mampu menaklukkan lawannya dan membuatnya kewalahan dalam menghentikan gerakan-gerakannya. Bahkan hebatnya berkat pengaktualisasian pesan-pesan Allah yang disampaikandalam Al-Qur'an dapat menaklukkan lawannya walaupun tanpa bersitegang seperti kejadian dengan Haji Agus Salim yang awalnya diutus untuk memata-matai HOS Tjokroaminoto pada saat terdapat isu bahwasanya Serikat Islam akan melakukan perlawanan bahkan pemberontakan bersenjata menggunakan bantuan asing yaitu Jerman. Haji Agus Salim kemudian menjadi patner dalam perjuangan yang dilakukan oleh HOS Tjokroaminoto yang menemaninya hingga akhir kehidupannya. Sebagaimana yang dikatakan oleh Haji Agus Salim:

"Perkenalan pertama saya dengan organisasi ini ... terjadi pada saat saya menjadi anggota seksi politik polisi. Saya diminta untuk menyelidiki kebenaran tentang rumor yang mengatakan bahwa HOS Tjokroaminoto telah menjual Serikat Islam kepada Jerman seharga f150.000; dan dengan uang ini memungkinkannya melakukan pemberontakan berskala luas di Jawa yang disuplai senjata oleh Jerman. Dari semula saya meyakini duahal: Pertama, bahwa rumor itu nonsense, dan kedua, bahwa jika pemberontakan itu menjadi kenyataan, ia hanyalah 
mengakibatkan malapetaka besar bagi negeri dan rakyat. Saya terimalah tugas saya juga beritahukan atasan perwira saya tentang keyakinan di atas ... penyelidikan itu membawa saya pada pengetahuan yang lebih mendalam mengenai Serikat Islam, terutama tentang kepemimpinan HOS Tjokroaminoto dan ini menyebabkan saya turut serta dalam gerakan itu, setelah itu saya putuskan hubungan saya dengan kepolisian".

Dengan semangat kemerdekaan, persamaan, persaudaraan yang benar-benar dipegang oleh HOS Tjokroaminoto dengan berpedoman penuh kepada nilai-nilai keislaman yang menjadi panutan sebagai penuntun dalam setiap langkahnya. Maka sangatlah wajar ketika dirinya menjadi magnet perekat dalam menggalang persatuan masyarakat yang sedang mengalami ketimpangan social akibat diskriminasi dan dominasi yang dilakukan Imprealisme barat dalam hal ini Belanda.

Bahwasanya kemudian buku memeriksai alam kebenaran menjadi karya magnum opus dari karya-karya beliau. Karena sejatinya ketika kita mampu menembus ruang-ruang kebatinan yang begitu mendalam tiada lagi aku dan kamu yang ada hanyalah kita yang satu. Itulah yang benar-benar dirasakan oleh HOS Tjokroaminoto pada saat itu sehingga upaya-upaya yang sedang menjadi kesenangan masyarakat pada saat itu juga diakomodir dengan melihat nilai-nilai keislaman.

Sebagaimana ajaran sosialis tentang konsep sama rata sama rasa telah menjadi keinginan setiap masyarakat maka dimasukkanlah nilai-nilai keislaman oleh HOS Tjokroaminoto dengan memberikan penyadaran bahwa sejatinya islam telah melakukan itu pada zaman dahulu dengan tidak adanya perbedaan antara penganut islam ketika menunaikan ibadah haji, saat menunaikan sholat atau salah satu tujuan turunnya Rasulullah adalah untuk membebaskan perbudakan karena rusaknya moral masyarakat Arab pada saat itu yang benarbenar tidak memperlakukan seorang wanita sebagai manusia. Dan juga dibeberapa tempat Rasulullah mendamaikan suku-suku yang sedang konflik dan terbentuklah persaudaraan dan persatuan.

Dengan tidak melupakan poinnya dengan mengembalikan semua itu pada nilai-nilai ketuhanan karena HOS Tjokroaminoto menyadari bahwasanya allah tuhan yang maha esalah yang menjadi tempat berawal dan kembalinya segala sesuatu. Hal ini terefleksikan pada tulisan HOS Tjokroaminoto dalam Islam dan Sosialisme yang mengutip Al-Qur'an surah 56 yang berarti "Kami tidak menciptakan Jin dan Manusia, melainkan dengan maksud supaya mereka beribadah kepadaku" dengan menuliskan;

"Menurut firman dalam ayat tersebut, tujuan hidup manusia yang sesungguhnya adalah untuk mengenal dan berbakti kepada tuhan, serta sama sekali taat dan tunduk kepada perintah allah. Dengan demikian semua perkataan dan perbuatan, tidak lain hanyalah untuk berbakti dan melayani allah belaka. Barang siapa berbakti benar-benar kepada allah, maka kebaktiannya yang benar-benar itu akan menjadikan usaha dan perbuatannya bermanfaat bagi kehidupan masyarakat. Barang siapa berkata atau mengaku berbakti kepada allah, tetapi ia tidak berusaha atau bekerja untuk kepentingan pergaulan hidup bersama, maka dustalah perkataan atau pengakuan tersebut." (Tjokroaminoto:1924)

Dalam pandangan penulis kemudian HOS Tjokroaminoto benar bisa dikatakan melampaui zamannya atau kita sebagai masyarakat yang tidak mengalami perkembangan sama sekali. Oleh karena isu isu yang menjadi perhatian HOS Tjokroaminoto hingga hari ini belumlah terselesaikan dengan maksimal. Seperti halnya kecintaan terhadap tanah air, dan juga bagaimana mekanisme pengelolaannya. Entah itu menggunakan penggabungan antara agama dan negara atau dengan pemisahan antara agama dan negara. 


\section{Dzulkarnain Jamil}

Masalah tersebut merupakan isu-isu yang juga menjadi perhatian HOS Tjokroaminoto pada masa lalu dengan dibuktikan oleh Perebutan kekuasaan di kalangan murid-murid HOS Tjokroaminoto. Seperti Semaon, Kartosoewirjo, dan Soekarno. Dan isu isu tersebut juga hingga saat ini masih menjadi perhatian yang paling krusial dalam pengelolaan sebuah negara bangsa.

Selain itu, hal ini juga berkaitan erat dengan persoalan ideologi kapitalis, komunis dan lain semacamnya. Bahkan hal tersebut merupakan masalah yang benar-benar memisahkan masyarakat sebagaimana yang terjadi dahulu pada zaman HOS Tjokroaminoto yang menjadikan Serikat Islam terbelah pada tahun 1917 menjadi Serikat Islam Putih yang dipimpin HOS Tjokroaminoto dan Serikat Islam Merah yang dipimpin oleh Semaoen. Dan perbecahanperpecahan di tubuh Serikat islam dengan tetap pada isu yang sama yang hingga hari ini menjadi perpecahan di Indonesia sendiri yang hal tersebut menjadi bahasan HOS Tjokroaminoto dahulu kala. Seperti yang terjadi pada ideologi-ideologi yang tertanam dalam partai-partai politik saat ini.

Hari-hari Terakhir H.O.S Tjokroaminoro, Selanjutnya HOS Tjokroaminoto mengalami kegalauan pada perjuangan-perjuangannya yang mengalami begitu banyak hantaman dari segala penjuru entah dari dekat maupun dari jauh. Entah dari dalam serikat islam ataupun dari luar serikat islam. Hingga akhirnya perenungan-perenungan HOS Tjokroaminoto atas cobaan dalam perjuangannya tersebut membawanya kembali menghayati bagaimana perjuangan suri tauladan yaitu Rasulullah SAW yang merupakan tokoh juga mendapatkan berbagai macam hantaman dari segala penjuru saat-saat beliau menyebarkan agama islam.

Pada akhirnya peristiwa tersebut membuat Nabi Muhammad SAW Hijrah dari Mekkah yang merupakan tanah kelahirannya sendiri menuju Madinah yang nantinya jadi tempat beliau wafat. Perpindahan tersebut dilakukan atas siasat yang dimilikinya sebagai bentuk perjuangannya untuk menciptakan peradaban baru dari masa Jahiliyah menuju era Islamiyah. Padahal jika dibandingkan dengan kehidupan sebelumnya di Mekkah Rasulullah SAW telah hidup mewah dan kepindahannya membuatnya hidup sederhana.

Pelajaran penting yang dapat diambil adalah totalitas dan ketulusan dalam perjuangan perubahan kearah lebih baik haruslah bersiap menghadapi masa-masa keterpurukan, kesusahan. Akan tetapi dari kisah Rasulullah tersebut berbuah manis dan indahnya islam yang dirasakan manusia diberbagai penjuru dunia hingga saat ini. Begitu pula perjuangan yang dilakukan oleh HOS Tjokroamino dalam memperjuangkan kemerdekaan tanah Nusantara ini telah melahirkan manisnya proklamasi. Oleh karena kejadian tersebut HOS Tjokroaminoto benar-benar menyadari bagaimana perjuangan panjang yang melelahkan tersebut tiadalah ada artinya sama sekali dibanding dengan bagaimana perjuangan nabi Muhammad dalam menyebarkan islam. Pada waktu-waktu tersebut HOS Tjokroaminoto menyelami kembali dan menenggelamkan diri dengan romantisme kehidupan Nabi Muhammad dalam berjuang.

Keadaan tersebut membawa HOS Tjokroaminoto yang sedang dirundung kegalauan akhirnya Beliau menghilang dalam hal itu dapat dipandang bahwasanya beliau mencoba menceraikan dunia ini yang dibuktikan dengan karya memeriksai alam kebenaran yang merupakan salah satu tangga yang dapat digunakan sebagai pijakan dalam berjalan meraungi kehidupan di dunia ini agar senantiasa meleburkan diri dengan sang pencipta. Sehingga tidak lagi menganggap setiap langkahnya berasal dari dirinya melainkan sudah menjadi tujuan awal penciptaannya yaitu membawa lentera ditengah gelapnya kehidupan dunia. Dengan tetap berlandaskan nilai-nilai religius Sebagaimana dalam tulisannya Memeriksai Alam Kebenaran yang mengatakan;

"Tidak bisa menoesia menjadi oetama jang sesoenggoeh-soenggoehja — tidak bisa manoesia mendjadi besar dan moelia dalam erti kata jang sebenar-benarnja,-tidak bisa ia mendjadi berani dengan keberanian jang soetji dan oetama, kalua ada banjak barang jang ditakoeti dan disembahnja. Keoetamaan, kebesara, kemoeliaan, dan keberanian jang demikian itoe hanjalah bisa tertjapai karena,, 
Tauhid" Sadja, Tegasnja Menetapkan lahir dan bathin: tidak ada sesembahan melainkan Allah sadja-(La ilaha illa'llah") sebagai jang dinjatakan dalam Qoeran Soertji soerah Al-Baqarah : 63" (Tjokroaminoto:1928)

Dengan itu dapat dimaknai bahwasanya peradaban yang dibangun oleh HOS Tjokroaminoto adalah proyek menyatukan diri dengan kehendak pencipta.

Sebagaimana yang dilakukan dahulu oleh syeh siti jenar yang mengajak masyarakat untuk memaknai hakikat ibadah dengan lebih mendalam seperti manunggaling kawula gusti. Akan tetapi hal begitu tidaklah mudah untuk disampaikan dengan bahasa yang seadanya dan dengan masyarakat yang masih baru mengenal islam sehingga yang terjadi adalah kekhawatiran oleh wali-wali yang lain tentang pemahaman masyarakat nantinya. Yang akhirnya dalam beberapa literature disebutkan bahwasanya Syeh Siti Jenar dihukum mati. (Suryaatmana:1994)

Bukanlah sesuatu yang mudah dalam mengajak menyatukan hakikat kehidupan pada kesejatian akan tetapi HOS Tjokroaminoto mencoba itu dengan memberikan pengertian pengertian dengan bahasa yang sederhana dan pedoman-pedoman seperti reglemen umat islam yang ditulisnya pada tahun 1934 sekaligus prakteknya dalam kehidupan sehari-hari yang mengedepankan nilai-nilai religiusitas. Makanya banyak kemudian yang khawatir tidak mampu meniadakan dirinya dengan meninggalkan dunia dengan menikmati kesendiriannya di gununggunung atau tempat sepi dengan meninggalkan anak dan istrinya.

Karena mereka khawatir sesuatu yang berada diluar dirinya tersebut dapat menyeretnya pada lembah kehinaan tanpa makna kehidupan. Sesuatu yang dilakukan oleh HOS Tjokroaminoto pada detik-detik terakhir kehidupannya merupakan bukti keberaniannya dengan menjadi guru yang turun gunung untuk menarik masyarakat disekitarnya pada jalan kesejatian yang merupakan tujuan akhir keberadaan. Seperti dalam salah satu kitab, Imam as-Suyuthi dalam kitabnya, ad-Dur al-Mantsur (jilid 6, hlm 177) yang menceritakan tentang peran-peran diambil oleh manusia.

"Dari Ibnu Mas'ud RA, katanya, 'Rasulullah SAW telah bersabda kepadaku, tahukah kamu, siapakah orang yang paling cerdas itu?' Maka kujawab, 'Allah dan Rasul-Nya lebih tahu.' Kemudian Rasul menjelaskan, 'Orang yang paling cerdas adalah orang yang paling awas melihat kebenaran di kala manusia gemar berselisih paham, meskipun amal perbuatannya minim, meskipun ia hanya bisa merangkak di atas kedua tumit kakinya. Masyarakat bani Israil terpecah ke dalam 72 kelompok. Tiga dari sekian banyak kelompok itu akan selamat, sedangkan sisanya akan celaka'.' 'Nabi SAW lalu menjelaskan tiga kelompok tersebut. Pertama, orang yang giat menentang (oposan) raja (penguasa) dan melawannya dengan dasar keyakinan agama Allah dan agama Nabi Isa Ibn Maryam, sehingga mereka semua terbunuh. Kedua, mereka yang tidak mempunyai nyali untuk menentang dan melawan penguasa waktu itu, namun mereka menegakkan agama Allah di tengah para pemuka masyarakatnya. Kemudian mereka menyeru masyarakatnya agar berpegang pada agama Allah yang dibawa oleh Isa Ibnu Maryam (Islam), sehingga mereka kemudian diciduk penguasa dan dibunuh serta dipotong-potong tubuh mereka dengan gergaji, kelompok ketiga, adalah mereka yang tidak punya kekuatan melawan raja (penguasa waktu itu) dan tidak juga punya kemampuan untuk mengajak masyarakat dan kaumnya pada agama Allah yang dibawa Isa Ibnu Maryam, sehingga mereka hanya bisa mengembara di pegunungan dan menjadi paderi di sekitarnya. Mereka inilah orang-orang yang disebutkan oleh Allah dalam firman-Nya, "Dan mereka mengada-adakan rahbaniyyah (tidak menikah dan mengurung diri di dalam biara), padahal Kami tidak pernah mewajibkannya kepada mereka, namun (mereka sendirilah yang mengada-adakannya) guna mencari keridlaan Allah, lalu mereka tidak memeliharanya dengan pemeliharaan yang semestinya. Maka Kami berikan 


\section{Dzulkarnain Jamil}

kepada orang-orang yang beriman di antara mereka pahalanya dan banyak di

antara mereka adalah orang-orang fasik." (QS al-Hadid: 27). (Basri:2016)

Ditengah carut marut keadaan alam utamanya tanah nusantara yang mengalami dinamika perjuangan begitu massifnya seperti halnya terjadinya peristiwa sumpah pemuda yang dicetuskan pada saat kongres pemuda II pada tanggal 28 Oktober 1928 yang dihadiri oleh perhimpunan pemuda/pemudi termasuk Perhimpunan Pelajar-pelajar Indonesia (PPPI) Jong Java, Jong Sumatranen Bond, Jong Ambon, Sekar Rukun, Jong Islamieten Bond, Studerenden Minahasaers, Jong Bataks Bond, Pemuda kaum Theosofi, Jong Celebes, Katholikee Jongelingen Bond pemuda kaum betawi dan masih banyak lagi.

HOS Tjokroaminoto benar-benar menyadari hal yang demikian dan sebenarnya ingin memberikan pedoman agar mereka para anak-anak muda tersebut tetap melihat bagaimana perjuangan jangan sampai melupakan nilai-nilai keislaman. Hal itu dibuktikan dengan bahasa yang digunakan adalah bahasa familiar bagi anak muda dalam bukunya tarikh agama islam yang terbit pada tahun 1927. Sehingga buku tersebut dapat dijadikan pedoman bagaimana agama islam telah merubah peradaban dunia di tengah-tengah kekuasaan kerajaan Romawi dan Konstantinopel yang begitu besarnya. Akan tetapi keluhuran nilai-nilai yang disampaikan oleh agama islam melalui Rasulullah SAW turut memberikan pengaruh terhadap keberadaan dunia hingga saat ini.

Benar saja bahwasanya kemudian pada puncak kenikmatan HOS Tjokroaminoto dalam meniadakan dirinya beliau tetap menjadi guru tak menikmati itu sendirian. Pada waktu yang sama HOS Tjokroaminoto sedang berjuang melawan sakitnya pada akhir tahun 1933 yang kemudian kembali kepangkuan sang pencipta pada tanggal 17 Desember 1934 di Jogjakarta. Hembusan nafas terakhirnya telah menandai keberangkatannya menuju kehidupan yang lebih abadi. Akan tetapi kemuliaan dan ketulusan hatinya walaupun dalam keadaan demikian yang dipikirkannya terakhir adalah bagaimana keadaan nasib-nasib umat islam nantinya setelah sepeninggalannya. Olel sebab itu kemudian beliau menuliskan wasiat-wasiat pada saat terakhir masa hidupnya.

Reglement wasiat pedoman ummat merupakan peradaban ideal yang dimaksudkan oleh HOS Tjokroaminoto dalam menata kehidupan umat islam baik persoalan Individu maupun kolektif dengan tidak meninggalkan nilai-nilai religiusitas. HOS Tjokroaminoto mengajak masyarakat dalam menjalani pergerakan dalam perjuangan juga tidak melupakan untuk memungut dan mengarungi mutiara-mutiara yang berada pada bagian terdalam kehidupan dan perjuangan sehingga apapun yang menjadi perjuangannya nanti dapat dituai oleh generasi berikutnya dengan manis. Sebagaimana murid-murid HOS Tjokroaminoto menunai hasil perjuangan HOS Tjokroaminoto dengan hadiah manis berupa kemerdekaan yang nantinya di proklamirkan oleh Ir. Soekarno murid biologis beliau.

Maka dari itu dapatlah dimasuki ruang-ruang perasaan HOS Tjokroaminoto pada saat itu benar-benar meniadakan dirinya dengan menekankan pada kepentingan umat. Dalam meneladani perjuangan HOS Tjokroaminoto yaitu hakikat perjuangan yang harus kembali diperbaiki dalam diri sendiri sebelum memperjuangkan nasib orang lain. Sehingga dalam perjuangan-perjuangan tersebut tidaklah berambisi untuk menunjukkan eksistensinya.

Kerendahan hati tetap saja melekat dalam jiwa seorang pejuang sejati. Sebagaimana yang dikatakan pada kongres terahir yang diikutinya pada tahun 20-26 Mei 1934 beliau mengatakan:

"Reglement umum bagi ummat islam sekarang sudah saya karangkan ... penting lantaran dari beberapa Ayat Al-Qur'an dan banyak hadits yang dipergunakan sebagai alasan, padahal yang bertanda tangan dibawah ini (pengarangnya rancangan) masih terlalu jauh sekali dari sifat pandai dan alim dalam ilmu-ilmu Agama Islam, maka sangatlah pengharapan saja, supaya: . . . Keempat, yang bertanda tangan di bawah ini sangatlah berharap supaya dibenarkan apa-apa yang 
dianggap salah, dan supaya di vooorstelkan buat dibuang saja apa-apa yang dianggap tidak perlu akan dimaktubkan dalam reglemen tersebut.' (Tjokroaminoto, 1934)

Maka dari itu nama beliau pun pada akhirnya telah menjadi butiran debu yang berada dibagian bawah terendah manusia. Karena secara kasat mata tidak lagi mengalami kenikmatan dalam hidupnya walaupun pada hakikatnya HOS Tjokroaminoto benar-benar menikmati samudera kehidupannya yang luhur.

Nama beliau tidaklah seterkenal pejuang-pejuang lain. Bahkan masa akhir hidupnya beliau numpang wafat dirumah orang karena saking sudah tiada apa-apa lagi yang dimilikinya.S pelajaran pentingnya dapat dilihat bahwasanya HOS Tjokroaminoto tidak lagi mementingkan sebuah pengakuan. Persatuan dan kesatuan untuk kehidupan umat yang sesuai dengan ajaran Islam agar senantiasa diutamakan.

\section{Simpulan Dan Saran}

Pembangunan Merefleksikan kembali pemikiran Religiusitas berkebangsaan H.O.S Tjokroaminoto. Selanjutnya demikianlah perjuangan HOS Tjokroaminoto haruslah dihayati oleh generasi-generasi berikutnya. Jika tadi disebutkan dimasa lalu HOS Tjokroaminoto telah mewakafkan dirinya untuk kepentingan dan kemaslahatan umat yang pengaruh pemikirannya hingga saat ini dapat dirasakan. Sehingga pesan-pesan suci yang disampaikan oleh HOS Tjokroaminoto seperti halnya kemerdekaan dan kemaslahatan masyarakat haruslah tetap mengedepankan nilai-nilai Religius dengan budi pekerti yang luhur. Sudah semestinya rekonstruksi ulang Gerakan Politik Islam Indonesia dipikirkan lagi jika melihat keadaan bangsa Indonesia yang dahulu menjadi perjuangan HOS Tjokroaminoto telah terkotak-kotakkan dengan begitu massifnya. Sehingga yang perlu dilakukan adalah memulai untuk mendaur ulang peradaban ini. Sebagaimana yang dikatakan oleh Aji Dedi Mulawarman dalam buku Jang Oetama Jejak dan Perjuangan HOS Tjokroaminoto:

"Sudah saatnya kita perlu desain kebaruan organisasi, desan kebaruan Ghirah. Serekat Islam Baru adalah wadah bagi pejuang idealis manusia Indonesia yang selalu resah untuk membangun Indonesia berpihak, berkeadilan menuju Rahmatan lil 'alamin, sekaligus menjadi bagian dari pusaran dunia islam, bahkan pusat pergerakan se-luruh dunia. Serikat Islam bukanlah bagian dari pusat du-nia. Bukan aku, atau mereka, tetapi kitalah pusat dunia itu. Kitalah, Serekat Islam. Serekat Islamlah pusat dunia itu. Serekat Islam baru Adalah wadah bagi perwujudan politik ber-akhlak karimah, dengan ketinggian ilmu penuh cinta kepada allah, muhabbatullah, cinta utama bagi seluruh ummah" (Mulawarman:2020)

Sebagai bentuk pertanggung jawaban atas yang telah dimulai oleh HOS Tjokroaminoto maka beban moral bagi kita apabila membiarkan apa yang telah diperjuangkan oleh HOS Tjokroaminoto dibajak oleh orang yang hanya mementingkan dirinya, keluarganya dan golongannya saja sebagai ajang untuk kemakmuran dan kesenangan pribadi. Sebagaimana kalimat terkenal Ir.Soekarno "Jangan sekali-kali melupakan sejarah". Maka untuk memulai itu semua, belajar kepada sejarah adalah langkah yang tepat sebagai bentuk replikasi dan juga pembaruan terhadap gerakan perjuangannya. HOS Tjokroaminoto memberikan empat langkah dalam menyiapkan kemerdekaan yaitu :

"Pertama, politik konsolidasi organisasi yaitu gerakan berjiwa kebersamaan. Kedua, gerakan social-ekonomi dilakukan melalui pembentukan koperasi di cabang-cabang Serikat Islam se-luruh Indonesia, serta bidang pendidikan dengan mendirikan Moslem National Onderwijs. Ketiga, penyebaran ideologi Sosialisme Islam melalui media dan diskursus pada awalnya tentang pentingnya 


\section{Dzulkarnain Jamil}

nasionalisme dan islam, kemudian melucuti komunisme pada anggota Serikat Islam, menulis Islam dan Sosialisme pada 1924, dan puncaknya adalah Memeriksai Alam Kebenaran (MAK) pada 1928 yang disampaikan pada kongres Jong Islamieten Bond ke-4. Keempat, melakukan gerakan relasional, dengan menjalankan agenda nasional, diantaranya aktif menjalankan mosi Tjokroaminoto di Volksraad tahun 1917 (Dewan Daerah) bersama Politeke Concentratie, menggagas gerakan Djawa Dwipa, membentuk tentara kanjeng Nabi Muhammad, mencetuskan federasi nasional PPPKI (PerhimpunanPerhimpunan Politik kebangsaan Indonesia) tahun 1927, kemudian Majelis Oelama pada 1928 yang merupakan cikal bakal Majelis Ulama Indonesia (MUI)". (Mulawarman:2020)

Salah satu solusi dari penulis jika melihat bagaimana keadaan Masjid dari pandangan penulis adalah melakukan gerakan pembaharuan Masjid untuk menjawab segala persoalan yang sedang terjadi di tengah Masyarakat. Masjid harus kembali menjadi sentral dalam berperan membantu umat manusia dalam membangun peradaban. Misalnya dalam persoalan kecil seperti buang air kecil dan membuang hajat ataupun tempat beristirahat saat ini masjid terlihat seolah menutup pintu dari orang yang sedang darurat karena banyak masjid telah dikunci pada jam-jam tertentu. Dan saat ini hal tersebut telah digantikan perannya oleh Toko-toko yang menyedian kamar mandi dan juga tempat mengisi bahan bakar sepeda motor atau mobil. Poinya bukan persoalan tersebut besar atau kecilnya kebutuhan orang, melainkan masjid dijadikan tempat pelarian terakhir ketika orang membutuhkan pertolongan. Sehingga terbangun menset bahwasanya masjidlah tempat segala masalah diselesaikan. Lebih jauh kita bisa melihat bagaimana zaman dahulu kala masjid merupakan tempat umat muslim mencari solusi atas permasalahan yang sedang dihadapi baik bidang ekonomi, sosial serta politik. Masjid bukan hanya tempat ritual belaka, melainkan tempat peradaban itu dikonsep. Hal tersebut sebetulnya telah disebutkan dalam Al-Qur'an surat Al-Baqarah ayat 125 disebutkan:

"Dan Ingatlah, ketika kami menjadikan rumah itu (Baitullah) tempat berkumpul bagi manusia dan tempat yang aman, dan jadikanlah sebagian maqom Ibrahim tempat shalat. Dan telah kami perintahkan kepada Ibrahim dan Ismail: "Bersihkanlah rumah-ku untuk orang-orang yang Thawaf, yang I'tikaf, yang ruku dan yang sujud", (QS. Al-Baqarah:125)

Maka, selain menjadi pusat ibadah masjid sudah semestinya dijadikan tempat berkumpul untuk membangun peradaban yang mengedepankan akhlak yang mulia. Sehingga ketika Masjid memiliki banyak fungsi akan melahirkan pemuda-pemuda yang ber-akhlakul karimah dengan mengedepankan hakikat Masjid. Jika saat ini dibeberapa Masjid tertulis "Dilarang membawa anak kecil" maka hal tersebut perlu dilakukan pembaharuan. Sebab anak-anak kecil dapat membangun peradaban yang beradab. Kebutuhan anak kecil haruslah diakomodir oleh Masjid seperti menjadi pusat pendidikan dan lainnya. Manfaat dari membangun peradaban masjid sebagai bentuk perlawanan terhadap massifnya gaget dalam menawarkan ketertarikan terhadap anak kecil seperti bermain Game dan lainnya, selain itu dunia industri juga yang mengajarkan perilaku hedonisme sejak dini kepada anak kecil haruslah dihentikan dengan sebuah perlawanan peradaban. Selain itu, tema-tema dalam pengajian dan khutbah agar memberikan pencerahan dan penyelesaian terhadap persoalan masyarakat dan juga para remaja sehingga dapat meningkatkan dirinya dari segi intelektual dan moral. Tema-tema bisa merupakan pendidikan politik dan kegegaraan, pengembangan zakat dalam dunia masjid ataupun pengembangan usaha. Jika kita mau melihat di seluruh Indonesia ada berapa ribu masjid yang uang kas-nya hanya disimpan tanpa diputarkan dan hanya digunakan ketika akan melakukan renovasi secara besarbesaran.

Sedangkan masyarakat yang tinggal disekitaran masjid ketika membutuhkan modal dan untuk memenuhi kebutuhan hidup menyandarkan diri pada Bank konvensional dan pegadaian untuk melakukan transaksi peminjaman dana. Maka alangkah Dzolimnya Masjid dalam konteks 
itu tidak mampu meriplikasi sebagaimana yang terjadi pada Masjid Nabawi dan Masjidil haram yang disekitarnya berdiri pasar-pasar raksasa. Kemudian saat Rasulullah hijrah dari Mekkah menuju Madinan beliau membangun masjid terlebih dahulu. Hal tersebut dalam pandangan penulis dilakukan guna menciptakan nilai persatuan dan kesatuan yang dikedepankan. Sebagaimana menciptakan pengajian-pengajian bersama bukanlah hanya satu golongan saja. Sehingga dapat melihat beragam prespektif namun tetap mengedepankan persatuan dan kebersamaan tanpa melakukan tudingan salah dan benar yang mengeras. Tentu dengan menanamkan nilai-nilai ke-esaan Allah sebagaimana yang dikatakan dalam Al-Qur'an surat AtTaubah ayat 18 disebutkan:

"Hanya yang memakmurkan masjid-masjid Allah ialah orang-orang yang beriman kepada Allah dan Hari kemudian, serta tetap mendirikan shalat, menunaikan zakat dan tidak takut (kepada siapapun) selain kepada Allah, maka merekalah orang-orang yang diharapkan termasuk golongan orang-orang yang mendapat petunjuk." (QS. At-Taubah:18)

Sehingga, dalam masjid nantinya dapat dilakukan Hijrah secara total. Sebagaimana yang dimaksudkan oleh Bapak Aji Mulawarman dalam bukunya yang berjudul Jang Oetama Jejak dan Perjuangan HOS Tjokroaminoto.

"Keikhlasan tertinggi ada pada jiwa Tjokroaminoto untuk Islam kesemestaan baru, yaitu kecintaan untuk memperbaiki negeri karena kecintaan kepada Allah, Mahabbatullah, yaitu Zelfbestuur baru, Zelfbestuur Tauhid, Nasionalisme Kesemestaan Berketauhidan. Untuk menuju zelfbestuur, Hijrah diperlukan sesegera mungkin melalui empat bagian, yaitu Perbaikan Sejarah, Demokrasi liberal menuju Musyawarah Mufakat, Ekonomi neoliberal menuju ekonomi kerakyatan berkeadilan social sebagaimana yang ada pada sila kelima Pancasila, dan Kebudayaan menuju manusia beradab karena kini manusia Indonesia telah kehilangan akar budaya sebagai dampak globalisasi”. (Mulawarman:2020)

Kalau sebelum kepergiannya HOS Tjokroaminoto menuliskan program dan wasiat-wasiat bagi masyarakat untuk melibatkan allah sebagai bentuk penyucian diri maka kedepannya memaknai hal tersebut bukanlah merasa suci dan benar sehingga yang terjadi bukanlah persatuan yang menyejukkan melainkan perpecahan yang menghancurkan.

Allah melalui Al-Qur'an dan Rasulullah telah memberikan pedoman kepada manusia yang semestinya menjadi pegangan yang erat dalam mengembangkan wawasan dan keilmuan yang dimiliki manusia dewasa ini. Maka sudah semestinya kedepan kita sebagai manusia yang berakal dan memiliki hati nurani untuk berendah hati dalam memperjuangkan apa yang memang menjadi kepentingan bersama karena itu merupakan kebutuhan yang mendasar untuk saat ini. Sehingga yang dapat dijumpai bukanlah argumentasi egois yang hanya mengklaim kebenaran secara subjektif. Melainkan kebenaran sejati dengan membawa nilai-nilai ke-esaan Allah. Kedepannya meributkan tentang salah dan benar jangan lagi terdengar pada telinga kita melainkan seberapa besar manfaat yang diberikan pada kehidupan. 


\section{Dzulkarnain Jamil}

Daftar Pustaka

Candra Kusuma Dkk. 2013. "Pengelolaan Alokasi Dana Desa Dalam Pemberdayaan Masyarakat Desa: Studi pada Desa Wonorejo Kecamatan Singosari Kabupaten Malang)". Jurnal Ilmiah. Universitas Brawijaya Malang: Malang.

Dickdick Sodikin, Djaka Permana, dan Suhenda Adia. 2017. "Manajemen Sumber Daya Manusia: Membangun Paradigma Baru".Jakarta: Salemba Empat

Edriana Pangestuti Dkk ,2018, "Peta Potensi Dalam Menciptakan Kemandirian Ekonomi Desa (Studi Pada Desa Tawang Argo,Malang)". Journal of Applied Business Administration Vol 2, No 2, Malang. Universitas Brawijaya.

https://id.m.wikipedia.org/wiki/Kemiskinan_di_Indonesia\#cite_ref-2 diakses pada 26 Februari 2020 pada pukul 20:43 WIB.

https://m.cnnindonesia.com/ekonomi/20191105154437-532-445788/angka-pengangguran-naikjadi-705-juta-orang-per-agustus-2019 diakses pada 26 februari 2020 pada pukul 20:44 WIB.

https://www.bps.go.id/publication/2019/07/04/daac1 ba18cae1e90706ee58a/statistik-indonesia2019.html diakses pada 26 Februari 2020 pukul 20:35 WIB.

Jaya Askar. 2004. “Konsep Pembangunan Berkelanjutan (Sustainable Development). Jurnal. Institut Pertanian Bogor : Bogor.

Kuswandoro, Wawan E. 2016. "Strategi Pemberdayaan Masyarakat Desa Berbasis Partisipasi”. Malang. Universitas Brawijaya.

Luthfia Rizka, A. 2013. "Menilik Urgensi Di Era Otonomi Daerah". Journal of Rural and Development. Vol IV, no 2.

M. Alamsyah, Nur. 2011. "Memahami Perkembangan Desa di Indonesia". Jurnal Academica Fisip Unitad. Vol 03.

Noor Munawar. 2011. "Pemberdayaan Masyarakat. Jurnal Ilmiah CIVIS Vol 1 No 2.

Poltak, Lijan Sinambela. 2012. "Kinerja Pegawai”. Yogyakarta: Graha Ilmu.

Pratiwi Dkk. 2018. "Analisis Implementasi Pembangunan Berkelanjutan Di Jawa Timur". Jurnal vol 18 No 1. Universitas Brawijaya: Malang.

Sri Mulyani Indrawati. 2017. "Buku Pintar Dana Desa". Jakarta: Direktorat Jenderal Perimbangan Keuangan.

Sugiyono. 2012. "Metode Penelitian Kombinasi (Mix Methods). Bandung: Alfabeta.

Supartini.2012. "Pemberdayaan Masyarakat Melalui Pengembangan Potensi Desa Wisata Ketingan Kabupaten Sleman-DI Yogyakarta". Yogyakarta. Akademi Maritim. Jurnal Nasional Pariwisata, Vol. 4, Nomor 1.

Syafaruddin. 2005. “Manajemen Lembaga Pendidikan Islam”. Jakarta: Ciputat Press.

T. Gilarso. 2004. "Pengantar Ilmu Ekonomi”. Yogyakarta: Kansius.

Wasisto Raharjo Jati,2015, "Bonus Demografi Sebagai Mesin Pertumbuhan Ekonomi: Jendela Peluang Atau Jendela Bencana Di Indonesia?”, Yogyakarta. Universitas Gadjah Mada dapat diakses melalui https://jurnal.ugm.ac.id/populasi/article/view/8559/6591

Wibowo. 2010. "Manajemen Kinerja”.Jakarta: Rajawali Press. 